\title{
Libyan ordeal ends: medics freed
}

A French government aircraft carrying six medical workers convicted of deliberately infecting children with HIV touched down in Sofia, Bulgaria, on 24 July, ending their 8-year ordeal in a Libyan prison.

The five Bulgarian nurses and a Palestinian doctor - given life sentences after more than 400 children contracted HIV at the hospital they worked at in Benghazi in 1998 - were immediately pardoned by Bulgarian President Georgi Parvanov. The charges, denied by the six, have been condemned as baseless by scientists, who argued that the outbreak was accidental and caused by inadequate sanitary precautions at the hospital.

Their release is the final scene

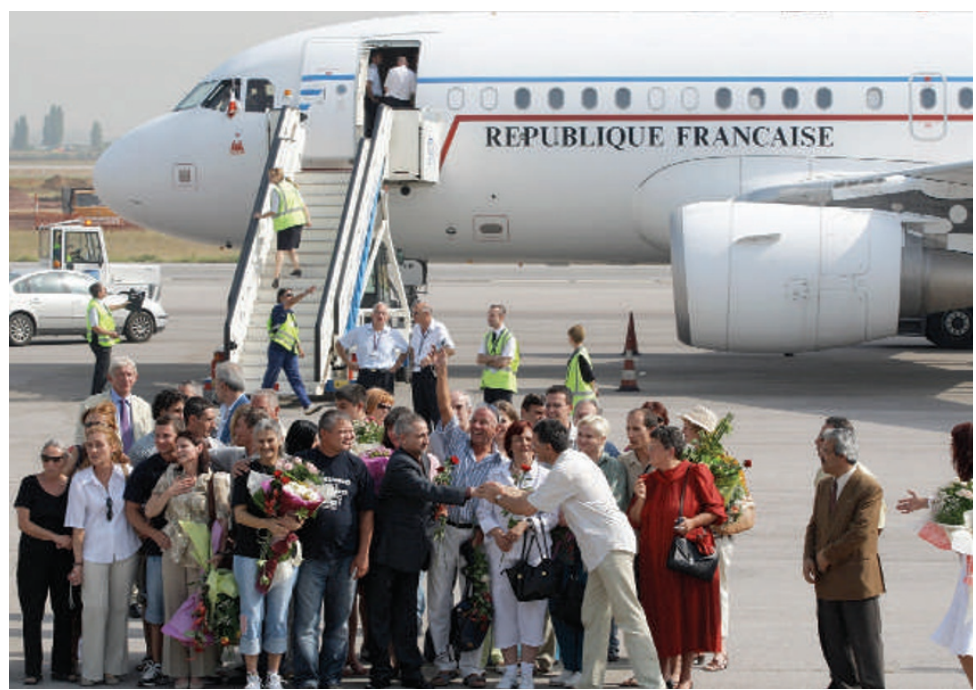

Sofia airport: Bulgarian president Georgi Parvanov pardons the medical team convicted of infecting Libyan children with HIV. in meticulously crafted negotiations between the European Union (EU) and Libya, which sought a way for Libya to climb down on the case without being seen to concede to Western pressure. Diplomatic efforts intensified as a result of international public and political outcry after the six medical workers were sentenced to death in a

Then, on 17 July, Libya's highest judicial body commuted their sentences to life imprisonment, over-ruling the death-penalty verdict upheld a few days earlier by the Supreme Court (see Nature 448, 230-231; 2007).

That move came after families of the children each received US\$1 million per child in 'compensation' from an international fund set up by the EU, Bulgaria and Libya. Nature understands retrial on 19 December 2006. that most of money is in fact likely to have been paid by Libya itself, and that the move allowed Libya to save face. The EU also agreed to provide humanitarian aid for long-term treatment of the infected children.

Libya has long used the six medical workers as bargaining chips and political pawns in its international relations. Right until the final hour of their release, Libya haggled to win further concessions to improve its political and trade ties with the EU.

Benita Ferrero-Waldner, the European commissioner for external relations, was also on the aircraft with the freed health workers. She, the EU and Britain, were the main players working patiently behind the scenes to secure the release. On the Libyan side, the key force in freeing the workers was Seif al-Islam Gaddafi, son of the Libyan leader Muammar al-Gaddafi, through his charity the Gaddafi Development Foundation. He is thought to be personally convinced that the outbreak was accidental.

More controversial is the role played by another passenger on the plane, French first lady Cécilia Sarkozy. France has not had a prominent role in the negotiations, and her lastminute intervention is widely considered to be a thinly veiled bid by her husband to steal the limelight that may, in fact, have weakened the EU's negotiating position in the talks.

"The efforts to mobilize Western governments to act by increasing international public opinion have paid off," says Emmanuel Altit, a lawyer from the medical workers' international defence team. The concerted efforts of the scientific community around the case played a "fundamental role" in changing the trajectory of the case and helping to secure today's outcome, he adds.

"It's great news," says Vittorio Colizzi, an AIDS researcher at Tor Vergata University in Rome, Italy, who campaigned for scientific evidence exonerating the medical workers to be considered by the Libyan courts. "But we must not forget the children," he adds, pointing out that the 1998 outbreak was a double tragedy - for the six unjustly imprisoned, and for the infected children and families.

Declan Butler

\section{Stem-cell researcher's move attracts funding}

James Thomson has added a parttime position at the University of California, Santa Barbara, to his current position at the University of Wisconsin, Madison. The new post is raising eyebrows because of recent strains between his home institution and the California Institute for Regenerative Medicine (CIRM) in San Francisco.

Thomson, a pioneering stemcell researcher, expects to spend around one month per year at his US\$1-million lab in Santa Barbara. But even that limited presence helped the university secure a \$2.3-million grant from the CIRM in June, noted blogger David Jensen on 15 July. And if some of the money granted to the university leads to breakthroughs it might also profit the state of California.

According to CIRM spokesperson Dale Carlson, discoveries made with CIRM money at such nonprofit institutions are owned by the institution. But the state of California can claim a share of revenue of more than $\$ 500,000$ generated on any resulting patents.

The prospect of California earning money from a Thomson discovery is noteworthy because researchers and watchdog groups have spearheaded a move to revoke patents for Thomson's work, owned by the Wisconsin Alumni Research Foundation in Madison, on key human embryonic stem-cell research (see Nature 447, 16-17; 2007).

$\mathrm{He}$ is not the only researcher to take a job in California that could bring in CIRM funding - his colleague at Wisconsin, Clive Svendsen, has arranged a part-time consultancy at Stanford University in Palo Alto.

Erika Check 